
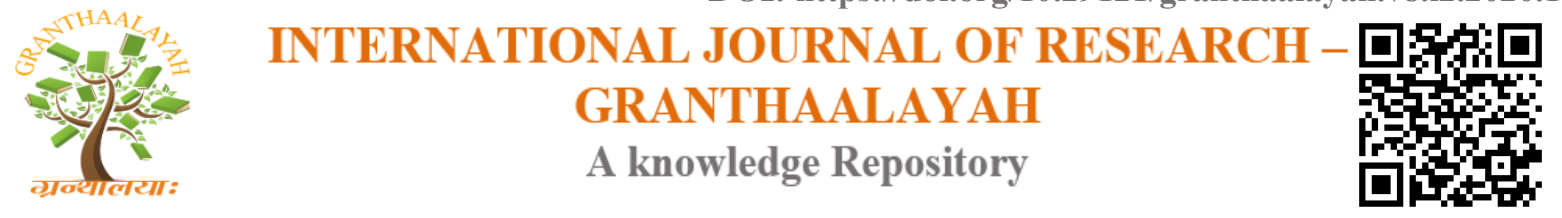

Social

\title{
TEACHING STRATEGIES USED IN CIVIC EDUCATION LESSONS IN SECONDARY SCHOOLS IN ZAMBIA
}

\author{
Magasu Oliver ${ }^{1}$, Muleya Gistered ${ }^{2}$, Mweemba Liberty ${ }^{3}$ \\ ${ }^{1}$ Kwame Nkrumah University-Kabwe, Zambia \\ ${ }^{2,3}$ University of Zambia-Lusaka, Zambia
}

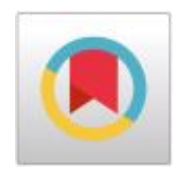

\begin{abstract}
This study sought to investigate the teaching strategies used in Civic Education lessons in secondary schools in Zambia. The study used a descriptive case study design and data was collected using interviews, Focus Group Discussions (FGDs) and observations. Purposive sampling procedure was used to target seventy-four participants. Data collected was analysed using themes that emerged from the literature review and objectives of the study. The main findings of the study were that teachers in secondary schools still used teacher-centred strategies in the teaching of Civic Education despite policy direction in the Zambia Education Curriculum of 2013. Lecture method was common most Civic Education lessons. A few who implemented reflective practice strategies in their lessons used debate, group discussions and brainstorming. Based on the findings, social sciences departments where Civic Education sits in secondary schools in Zambia should find mechanisms of observing reflective practice strategy in the teaching of Civic Education rather than just seeing lesson plans. The Ministry of General Education should take a deliberate move to provide workshops/short courses to Civic Education teachers on the importance and use of reflective practice strategy in Civic Education lessons. Further, Curriculum Development Centre (CDC) and Examination Council of Zambia (ECZ) should collaborate and re-design the Civic Education Syllabus and give it a practical project since the subject is practical in nature. There is need in future to assess the training of Civic Education teachers with regards to training for reflective practice strategy.
\end{abstract}

Keywords: Civic Education; Pedagogical; Reflective practice; Implementation.

Cite This Article: Magasu Oliver, Muleya Gistered, and Mweemba Liberty. (2020). "TEACHING STRATEGIES USED IN CIVIC EDUCATION LESSONS IN SECONDARY SCHOOLS IN ZAMBIA." International Journal of Research - Granthaalayah, 8(2), 39-46. https://doi.org/10.29121/granthaalayah.v8.i2.2020.182.

\section{Introduction}

Recent research in the last twenty years suggests that Civic Education is a field of vibrant research and practice that is producing significant pedagogical innovations (Carretero et al. 2016). As a result of this development, Likando (2019) notes that reflective practice strategies have become 
one of the most sort classroom instructional strategies in many countries around the world. Finlay (2008) defines reflective practice strategies as practices that involve adopting a thinking process to learning. By implication, the teaching of Civic Education should expose the learners to real life situations so that they learn from their experiences of life. Exposure to real life situation will trigger reflection and thinking, and makes education relevant to society. Essentially, this is a precursor for critical thinking. This view was supported by Muleya (2019) who observes that teaching and learning methods that encouraged learners to reflect upon their own situation and the circumstances and power structures they live in, help stimulate critical reflections that may lead to transformation and social change. This approach is consistent with the critical approach to education which is ideal for teaching Civic Education and has been emphasized in the Zambia Education Curriculum Framework of 2013 (MoE, 2013) where the focus is on. As a result of this development, curriculum reforms at secondary school level in Zambia has become unavoidable. This development further reflects a change in the teaching and learning strategies that are more participative like reflective practice in the teaching of Civic Education. Underlying this transition is a basic tension between pedagogy that emphasizes the acquisition of knowledge through teacher instruction and pedagogy that emphasizes praxis, interaction with tools, objects, experiences and people as the means to gain understanding (Carretero et al. 2016). This view was supported by Zeichner \& Liston (2014) who argues that the move towards seeing teachers as reflective practitioners is also a rejection of top-down forms of educational reform that involve teachers only as conduits for implementing programmes and ideas formulated elsewhere. By implication, teachers who used reflective practice were supposed to be facilitators in the process of learning and not fountains of knowledge.

Therefore, the study's aim was to investigate the teaching strategies used in Civic Education lessons in secondary schools in Zambia. The question this study sought to answer is, what teaching strategies are used in Civic Education lessons?

\section{Methodology and Design}

This study took a qualitative approach and employed a descriptive case study design. This study was conducted in Lusaka Province among five selected secondary schools namely: A, B, C, D and E. This study enlisted Seventy-four participants and among them were pupils, teachers, lecturers of University $\mathrm{Y}$ and $\mathrm{Z}$ and an official from CDC. Purposive sampling techniques was used to identify the participants. Interview guide, observation checklist and FGDs were used to gather data. Data from interviews and FGDs was transcribed having read text files and listened to the tape recorders thoroughly for a general understanding. Common themes were then identified and clustered to categorise the data. Relevant information was labelled and grouped to the according category. Furthermore, the data was then reduced to its essence and representative and most striking quotes were identified. Codes related to the objectives were identified and a thematic analysis was done. Throughout this process of categorising pattern, similarities and contrasting viewpoints are highlighted and critically interpreted on the basis of the theoretical framework.

\section{Presentation of Findings}

In order to respond to the objective of this study which sought to investigate the teaching strategies used in Civic Education lessons in secondary schools in Zambia, and the study objective was: 
To investigate the teaching strategies used in Civic Education lessons in secondary schools in Zambia

When the participants were asked to indicate the teaching strategies used in Civic Education lessons, this is what $\mathrm{T} 1$ had to say:

"For me I use methods such as debate, lecture, discussion, research project in my teaching of Civic Education ..."

However, when the pupils (in FGDs) were asked on how often debates and research projects were used and given respectively in Civic Education lessons, the pupils indicated that their teachers rarely involved them in debate and research projects. It was also discovered that in one Grade 11 class, the only time they had debate was once in Grade 10. Further, pupils indicated that when teachers involved them, they were able to remember information easily.

The views of these pupils reflected what L 2 from University Y observed. This is what he said: "Mostly the methodologies used in the teaching of Civic Education in Zambia is the banking model where the teacher stands in front and talks to the pupils..."

This view was further supported by a participant from the MoGE who observed that teachers rarely engaged participatory methods in lesson delivery. This is what he said:

"Lecture method dominate class activities and sometimes teachers even give notes to some pupils to write for their fellow pupils and in most cases such notes go unexplained by the teachers ... this is unfortunate..."

Another participant who is a teacher also mentioned that Civic Education teachers were encouraged to use active learning methods which put the learners at the centre of learning but such methods came with challenges. However, the participant was able to mention only two challenges. The first one being school administrations not being able to embrace learner centred strategies citing expenses. The other challenge had to do with over enrollments in secondary schools which hindered the use of learner centred strategies such as group discussion.

When the pupils were asked during FGDs if learner centred approach was a popular method of teaching Civic Education in secondary schools, it was clear from their responses that learner centred approaches were rarely executed.

It was evident from the participants that learner centred strategies required a strong collaboration among stakeholders to implement. In responding to whether teachers had competencies in using learner centred strategies in the teaching of Civic Education, $\mathrm{T} 1 \mathrm{had}$ this to say;

"Lack of use of active civic learning methods was due to school arrangement concerning timetable of 40 minutes. Again such methods require a lot of time and careful planning. There are less incentives to encourage us to actively engage participatory methods as school management every time complain that the school has no money but the school bus is seen making several trips to town ..." 
The above mentioned view seemed to have been supported by a number of teachers in separate interviews. A female teacher bitterly complained that; school management did not help with necessary support to encourage teachers to use active methods, for example, when it was time for sports money is found but when you request for a study tour, money was never there. She further requested for administration support if learner centred strategies were to be embraced in the teaching of Civic Education. It was also evidently clear that even pupils got excited to move away from the usual classroom arrangement because knowledge retention was high when pupils were exposed to experiential learning within the community of practice or outside school premises.

A participant from the Zambia Civic Education Association (ZCEA) noted that the impact of Civic Education had made in Zambia was insignificant because of the methods teachers were using. The subject was delivered as a theory based subject. Pupils were not exposed to community based practices, this had a negative bearing on participative skills in the pupils and in the implementation of reflective practice.

This is what was said:

"Learners are not engaged in real issues affecting them and the society. Methods used are just confined to the classroom. Given a chance, I would ensure Civic Education has a practical where the learners are attached to a community project and were assessed from there. This is the only way they can find meaning in what they are learning."

Additionally, discovery method was mentioned by one of the participants, a teacher, but could not elaborate further on how this method of teaching resonated well with Civic Education. When asked further to explain how a teacher could use discovery method, the participant had to mention lecture method and group discussion. This state of affairs made me suspect that this participant was not well-vested with reflective practice strategies in the teaching of Civic Education. It also emerged from this interview that teachers of Civic Education rarely involved pupils in activities of group work, participation and community service which were key elements of Civic Education. Active pupil engagement stimulates critical thinking, innovation and reflection to solve societal challenges.

However, T 1 mentioned in the interview that learner centred strategies such as discussions, debates, problem solving and others were used in the teaching. The participant went on to add that the methods were capable of transforming the pupils to be responsible citizens in society. This is what T 1 said:

"Unlike these other subjects, we are so much into learner centred strategies. We always engage our pupils into group discussions and we also involve them in presentations. We believe this would help our pupils to become good public speakers and generate self-esteem; we also give them assignments to research when they are on holiday. By giving them assignments, we want them to acquire the knowledge, skills and proper attitudes but also engage them in practical aspects of life."

However, when I observed Civic Education lessons, the findings did not confirm that teachers were using learner centred strategies. Lessons were mostly characterized by lecture method. 
"Sometimes even teachers fear to teach controversial issues or topics especially those bordering on political, social issues affecting citizens."

A participant from ZCEA mentioned that teachers should be preoccupied with fostering skills of evaluating, taking, and defending positions among the learners so as to activate critical minds for civic engagement. When asked whether pupils had skills of evaluating, taking and defending positions, one teacher during the interviews suggested that it would be of help to pupils to create an award or scholarship for outstanding achievement in Civic Education and encourage programmes such as junior president on Zambia National Broadcasting Corporation (ZNBC) and sites like www.africanleadershipacademy.org as they help build confidence in the learners when talking in public, make critical reflections, tolerance as well as enhancing the philosophy of common good and co-existence. Furthermore, this is what he said:

"Character development in civic skills and dispositions require systematic training and preparation for someone to function properly as a responsible citizen. As teachers we need to understand that skills such as public speaking, taking and defending positions do not just come automatically in human beings."

Following up whether pupils were adequately prepared in secondary schools to speak in public, debate and question authorities, all the teachers interviewed explained that debate, discussions, quiz and mock trials could greatly contribute and increase pupils efficacy in public speaking, questioning and defending positions. This is what one teacher said:

"It is important that we do more to prepare school children for their life beyond the classroom and for the role that they will have to play as citizens of this country."

\section{Discussion of the Findings}

\section{Current Pedagogical Trends in Civic Education Lessons}

It was established that most teachers of Civic Education still used the same old teaching methods to teach the subject. For instance, one teacher (T 1) said:

"For me I use methods such as debate, lecture, discussion, research project..."

The fact that teachers of Civic Education still use lecture method in the teaching of Civic Education means that they were experiencing challenges in the implementation of reflective practice strategy. Lecture method has a number of limitations. It does not promote interaction in most cases and communication is one way and in certain cases, learners usually get carried away by the charisma and personality of the teacher instead of focusing on analyzing what is being taught. The current trend could also mean that some teachers were not adequately trained to implement reflective practice. The practical aspect was lacking and this was seen as an impediment in the implementation of reflective practice strategies. The later calls for Colleges, Universities and Ministry of General Education to reorient the training curriculum for teachers of Civic Education to expose the trainee teachers to reflective teaching strategies. 
The findings discussed above are in line with the findings of Ornstein et al. (2000:123) who added that "trainee teachers are also expected to hold the mastery of content in their respective disciplines such as the ability to appreciate the philosophy of their subject, demonstrate adequate knowledge of the subject content, better grounding in appropriate pedagogical strategies, have understanding of various concepts and facts, and be able to acquire, assimilate and apply information in everyday teaching." The training was mainly centred on aspects that promote as (Freire ,1970) stated the banking type of education which in real sense failed to motivate would be learners in schools to become critical and think in a creative way and promote democratic citizenship ideals. The views above suggest that the nature and quality of Civic Education teacher education is an important element for building democratic citizenry and democracy in general.

Teacher-centred or lecture methods did not encourage learner participation and as such rendered irrelevant in the teaching of Civic Education in secondary schools in Zambia because they encourage passive learning in which the learning and teaching were directed by the teacher. This was seen as an impediment in the development of critical thinking skills. It appears most of the strategies that generated interest and debate among the learners in secondary schools in Zambia were rarely used in Civic Education lessons. From the lessons observed, it was clear that teachers relied mostly on traditional strategies such as lecture method in the teaching of Civic Education. By implication, this was denying the learners opportunities of engagement and real learning. This entails that if learners are to be engaged by teachers in the learning process, effective methods of teaching Civic Education should be practiced. This view was supported by Youniss (2011) who recommended that Civic Education classes were to be designed not to produce political scientists or historians but for preparing of young people or students for taking their place in the community and leading useful lives. This calls for reflective methods of teaching Civic Education.

As noted in the discussion above, the teaching strategies used by teachers of Civic Education in secondary schools in Zambia did not place the learner at the center of learning. As such, the role of Civic Education in secondary schools in Zambia was not appreciated. Therefore, these findings show lack of effective teaching methods in secondary schools with regards to the teaching Civic Education. This compromised the aim of Civic Education and could explain why it appeared the impact was insignificant. Kerr (1999) gives three major pedagogical strands of Civic Education that inform its approach to curricular issues. The three strands are; Education about Citizenship, Education through Citizenship and Education for Citizenship. Education about citizenship strives to provide learners with sufficient knowledge and understanding of national history and the structures and the processes of government and political life as done in traditional, classroombased Civic Education. Education through Citizenship involves learners in learning by doing through active, participative experiences in the school or local community and beyond. Education for Citizenship demands that learners should be equipped with a set of tools of knowledge and understanding, skills and aptitudes, values and dispositions. In the context of this study, it was clear that education through citizenship and education for citizenship supported the use of reflective practice in the teaching of Civic Education in secondary schools in Zambia.

From the responses presented, it was also clear that Civic Education did not prepare learners for real life experiences in Zambia. This was despite some teachers indicating that they used learnercentred strategies. By implication, the assertion that teachers of Civic Education were well placed and used learner-centred methods when teaching Civic Education was disputed by the findings in 
this study. This means that teaching and learning of Civic Education is supposed to engage the learners in the whole process of learning so that they could make meaningful contribution to society.

Dean (2007) observed that teachers were reluctant to supplement the Civic Education curriculum with activities that would teach learners to ask questions, think critically and develop problemsolving skills or conduct independent inquiries on issues and responsible action as learners were only prepared to get ready for the examination and would only be tested on textbook materials. As a result, he argues that there was a high stake value in end-of-year and school leaving examinations resulting in teaching and learning in schools being geared towards examinations. This means that Civic Education should be taken as a programme that is meant to prepare the learners and the citizens so that they can engage and participate in a democratic society (Ogunyemi, 2011).

\section{Conclusion}

In this article, an attempt has been made to investigate the teaching strategies in Civic Education in secondary schools in Zambia. It is undoubtedly clear that Civic Education teachers in Zambia still used the old traditional methods when teaching the subject. In conclusion, this article demonstrates that there is need to use reflective teaching methods in Civic Education if the learners were to develop critical minds.

\section{Theoretical Implications of Findings}

The findings in this study are consistent with the demands of the Zambia Education Curriculum Framework of 2013 and the theoretical framework adopted in this study where education is viewed as empowering, emancipating and enlightens. The failure by teachers to use reflective teaching strategies means that there were serious challenges with regards to the teaching of Civic Education in secondary schools in Zambia.

The fact that Civic Education was viewed ordinarily like any other academic subject and not an emancipating one, adds to the theoretical perspective that this study relied upon. Therefore, appropriate prior knowledge about the importance and how the subject should be taught should be designed and implemented. In this sense, the Zambia Education Curriculum Framework of 2013 should be implemented by all teachers of Civic Education if desired outcomes were to be actualised.

\section{Recommendations}

On the basis of the findings of this study, recommendations are hereby suggested;

- Since Civic Education is practical in nature, there is need for the MoGE, Examinations Council of Zambia and CDC to consider a practical assessment for Civic Education if the desired goals were to be achieved.

- Since teachers of Civic Education still use the old traditional ways of teaching, the MoGE should strengthen Continuing Professional Development (CPD) activities in secondary schools so that teachers of Civic Education are oriented to the contents of the Zambia Education Curriculum Framework. 


\section{References}

[1] Carretero, M., Haste, H. \& Bermudez, A. (2016). Civic Education. In L., Corno \& E. M. Anderman (Eds.) (2006), Handbook of Educational Psychology 3rd Edition, Chapter 22, pp. 295 - 308. London: Routledge Publishers.

[2] Dean, B.L (2007). Research Report on the State of Civic Education in Pakistan. Islamabad: Aga Khan University, Institute for Educational Development

[3] MoE (2013). Zambia Education Curriculum Framework 2013. Lusaka: CDC.

[4] Finlay, L. (2008). Reflecting on 'Reflective practice' PBPL A discussion paper prepared for PBPL CETL, The Open University, Paper 52: 1-27 (www.open.ac.uk/pbpl.

[5] Freire, P. (1970). Pedagogy of the Oppressed. New York, NY: Continuum

[6] Kerr, D. (1999). 'Citizenship Education in the Curriculum: An International Review,' The School Field, X (3/4), 5-32.

[7] Likando, M. (2019). Primary School Teachers Understanding of Reflective Practice in Lukulu and Mongu District of Western Province in Zambia. Journal of Humanities and Social Science 24(2) 46.

[8] Muleya, G. (2019). Curriculum Policy and Practice of Civic Education in Zambia: A Reflective Perspective. Lusaka: UNZA

[9] Ogunyemi, B. (2011). 'A Clash of Past and Present: Citizenship Education in Nigeria's Junior Secondary School Curriculum’ In European Journal of Social Sciences. Vol 18. No. 3, pp. 378385.

[10] Ornstein, A.C., Thomas, J. \& Lasley, I. (2000). Strategies for effective teaching. New York: McGraw Hill.

[11] Youniss, J. (2011). Civic Education: What Schools can do to Encourage Civic Identity and Action. Applied Developmental Science, 15(2), 98-103.

[12] Zeichner, K.M. and Liston, D.P. (1996). Reflective teaching: An introduction. Mahwah, NJ: Erlbaum.

${ }^{*}$ Corresponding author.

E-mail address: magasuo@yahoo.com/muleya71@yahoo.com/lmweemba69@yahoo.com 